\title{
Pericardial tamponade as a complication of invasive cardiac procedures: a review of the literature
}

\author{
Maria Adamczyk, Jarosław Wasilewski, Jacek Niedziela, Piotr Rozentryt, Mariusz Gąsior \\ $3^{\text {rd }}$ Department of Cardiology, Medical University of Silesia, Silesian Centre for Heart Diseases, Zabrze, Poland
}

Adv Interv Cardiol 2019; 15, 4 (58): 394-403

DOI: https://doi.org/10.5114/aic.2019.90213

\begin{abstract}
A bstract
Cardiac tamponade (CT) is a rare but often life-threatening complication after invasive cardiac procedures. Some procedures favor CT. Furthermore, the incidence depends on patients' comorbidities, sex and age and operators' skills. In this paper we review studies and meta-analyses concerning the rate of iatrogenic CT. We define the risk factors of CT and show concise characteristics for each invasive cardiac procedure separately. According to our analysis CT occurs especially after procedures requiring transseptal puncture or perioperative anticoagulation. The overall rate of CT after such procedures varies among published studies from $0.089 \%$ to $4.8 \%$. For this purpose we searched the PubMed database for clinical studies published up to December 2018. We included only those studies in which a defined minimum of procedures were performed (1000 for atrial fibrillation ablation, 6000 for percutaneous coronary intervention, 900 for permanent heart rhythm devices, 90 for left atrial appendage closure, 300 for transcatheter aortic valve implantation and percutaneous mitral valve repair with the Mitra-Clip system). The search was structured around the key words and variants of these terms. In addition, secondary source documents were identified by manual review of reference lists, review articles and guidelines. The search was limited to humans and adults (18+ years).
\end{abstract}

Key words: percutaneous coronary intervention, electrophysiology, pericardial tamponade, transcatheter aortic valve implantation, left atrial appendage closure, percutaneous mitral valve repair.

\section{Introduction}

Nowadays, open heart surgery procedures are being replaced with minimally invasive attempts. This trend has led to a growing number of invasive procedures in cardiology. Pericardial tamponade (PT) is one of the most severe complications after such procedures. In this paper we review studies and meta-analyses concerning the rate of iatrogenic PT and concisely present brief characteristics for each procedure separately.

\section{Pericardial tamponade as a result of catheter-based procedures}

PT occurs when the pressure in the pericardial space exceeds the pressure in one or more cardiac chambers. The occurrence of hemodynamic abnormalities and clinical symptoms depends on the rate of fluid accumulation relative to pericardial stretch and the effectiveness of compensatory mechanisms. Thus, abrupt intrapericardial content accumulation (i.e. hemorrhage from cardiac rupture) occurs in the context of a relatively stiff, unyielding pericardium and quickly overwhelms the pericardial capacity to stretch before most compensatory mechanisms can be activated. In those situations, volumes such as 50-100 ml of fluid may result in hemodynamic decompensation [1]. In the cases of slow increase in pericardial fluid volume there is more time for pericardial capacity to stretch and for compensative mechanisms to be activated, so even 2 I or more may accumulate before critical, life-threatening PT occurs [2].

latrogenic acute PT is a life-threatening complication that can lead to death. It often involves hemodynamic instability and requires cardiopulmonary resuscitation in $20 \%$ and blood transfusion in more than $25 \%$ of patients [3].

Within the cardiology lab, PT develops most often rapidly, usually as a result of perforation of the heart structures. The perforation may be caused by a guidewire, balloon dilator, sheath, pacemaker lead, or excessive ablation energy. The presentation depends in part on at least 5 factors: the size of the device responsible for the perforation, the structure that is perforated, such as atrial versus ventricular myocardium, left versus right

\section{Corresponding author:}

Maria Adamczyk MD, $3^{\text {rd }}$ Department of Cardiology, Medical University of Silesia, Silesian Centre for Heart Diseases, 9 Skłodowskiej St, 41-800 Zabrze, Poland, e-mail: maria.ester.adamczyk@gmail.com

Received: 27.08.2019, accepted: 21.10.2019. 
chamber, the hemodynamic state during perforation, mechanical properties of the pericardium itself, and the coagulation status. The thicker wall of the left ventricle (LV) $(\leq 10 \mathrm{~mm})$ may act to seal small perforations, balancing the higher intra-chamber pressures in contrast to the right ventricle $(\mathrm{RV})(\leq 4 \mathrm{~mm})$. Small perforation of the ventricles in a patient without anticoagulation may not be clinically apparent. Perforation of the left atrium (LA) is potentially much more serious, primarily because procedures involving the LA are always associated with anticoagulation, and because LA pressure is typically higher than RA pressure. The pressure within the structure that is perforated is a major determinant of the development and severity of PT. Thus, conditions such as pulmonary hypertension and aortic valve stenosis may significantly affect hemodynamic instability in PT [4].

The risk of iatrogenic PT or pericardial effusion increases with the need for transseptal puncture and intraprocedural anticoagulation [5]. With growing acceptance of retrograde catheterization of the left ventricle, the use of the transseptal technique for diagnostic purposes has declined. However, in recent years, substantial renewed application of the transseptal method has occurred for special diagnostic and therapeutic purposes [6]. The procedures requiring transseptal puncture are the following: patent foramen ovale and ventricular septal defect closure, percutaneous heart valve repair or replacement (for mitral regurgitation and aortic stenosis), LA appendage occlusion and electrophysiological procedures such as pacemakers or cardioverter-defibrillators implantation and ablation procedures within the left heart [6].

\section{Pericardial tamponade as a complication of atrial fibrillation ablation}

Mentioning atrial fibrillation (AF) ablation, PT was observed as the most frequent complication leading to death. The incidence of PT is higher than with other procedures that employ transseptal catheterization. PT may be characterized as acute when occurring during or immediately after the procedure, or delayed when detected later than $1 \mathrm{~h}$ after completion of the procedure [7].

There is evolution of catheter-based AF-ablation techniques. Radiofrequency catheter ablation (RFCA) and cryo-balloon ablation (CBA) are the two standard ablation systems used for pulmonary vein antrum isolation at present. Anticoagulation strategies posit that anticoagulation therapy should be administered prior to or immediately following transseptal puncture during AF catheter ablation [8]. PT may occur any time during trans-septal puncture, extensive catheter manipulation, application of RF energy or steam pops under an intense anticoagulation regimen [7].

According to the 2017 HRS/EHRA/ECAS/APHRS/ SOLAECE expert consensus statement on catheter and surgical AF ablation, the rate of PT after AF ablation rang- es from $0.2 \%$ to $5 \%$ [8]. It was based mostly on a prospective multicenter observational study performed by Cappato et al. [9], analyzing $45115 \mathrm{AF}$ ablations, where the incidence of PT was $2.3 \%$. In this study PT was found as the most frequent fatal complication leading to intraoperative pump failure or post-operative early cardiac arrest. From the reported 32 deaths, 7 occurred due to tamponade ( 5 as acute and 2 as late PT), in comparison to atrioesophageal fistulas, as the second most frequent fatal complication, counting 5 deaths. In another multicenter prospective study of 6065 Medicare patients, analyzed by Ellis et al. [10], the incidence of PT due to AF ablation increased from $1.3 \%$ in 2001 to $3.6 \%$ in 2006 . Patients who died experienced higher rates of perforation/tamponade $(12.0 \%$ vs. $3.1 \%$ in the remainder of the study sample, $p=0.01$ ).

In the study by Mujović et al. [11], in 2 of 12 cases, tamponade resulted in electromechanical dissociation and cardiorespiratory arrest, while in the remaining ten patients tamponade was associated with significant hypotension. Two patients required surgical treatment. Nine patients received blood transfusions; in seven of them auto-transfusion was carried out. It seems that direct auto-transfusion is simple and requires no additional equipment; it may abolish the need for allogeneic blood transfusion and can "buy" time until surgery [12]. However, direct auto-transfusion may cause systemic inflammation, and therefore the processing of the drained blood via the cell salvage system is recommended prior to its return [13]. Auto-transfusion of a larger volume of blood, i.e., more than $1500 \mathrm{ml}$, may lead to consumptive coagulopathy $[12,13]$, which occurred in one patient in this study. The rate of PT, its related mortality and management of PT after AF ablation procedures are summarized in Table I [9-11, 14-21].

Deshmukh et al. [22] had identified 93801 AF patients treated with catheter ablation obtained from the Nationwide Inpatient Sample (NIS) data set from 2000 to 2010. They observed that in patients older than 80 years, the catheter ablation of AF was associated with a significantly higher total complication rate $(9.37 \%$, $p<0.001)$. From this group, cardiac complications were the most frequent adverse outcomes (2.54\%). Within cardiac complications, CT was included but not defined alone. Also women overall had higher complication rates than men $(7.51 \%$ vs. $5.49 \%, p<0.001)$. A similar conclusion about sex differences was reached by Michowitz et al. [15], and Elayi et al. [23], who analyzed a group of 85977 patients undergoing catheter ablation of AF. In this group PT appeared in $0.7 \%$ of men vs. $1.3 \%$ of women $(p<0.001)$ and the rate of at least one major and overall complications was significantly higher among women than among men, but without a significant difference in mortality between groups.

There are studies [24-26] proving no significant differences in the frequency of pericardial effusions/peri- 
Table I. Studies concerning information about rate of pericardial tamponade as a complication of ablation of atrial fibrillation, PT-related mortality, management and outcomes, up to December 2018

\begin{tabular}{|c|c|c|c|c|c|c|c|}
\hline Author(s) [ref.] & $\begin{array}{l}\text { Type of } \\
\text { procedure }\end{array}$ & Type of study & $\begin{array}{l}\text { Time } \\
\text { interval }\end{array}$ & $\begin{array}{l}\text { No. of procedures/ } \\
\text { patients }\end{array}$ & $\begin{array}{l}N(\%) \text { PT per } \\
\text { all proce- } \\
\text { dures }\end{array}$ & $\begin{array}{l}\text { No. }(\%) \\
\text { PT-related } \\
\text { mortality }\end{array}$ & $\begin{array}{l}N(\%) \\
\text { PCC/ST }\end{array}$ \\
\hline Cappato [9] & $\begin{array}{l}\text { Catheter abla- } \\
\text { tion of AF }\end{array}$ & $\begin{array}{l}\text { Multicenter } \\
\text { prospective } \\
\text { observational }\end{array}$ & 1995-2006 & 45 115/32 569 & 2.3 & 2.11 & - \\
\hline Ellis [10] & RFCA of AF & $\begin{array}{l}\text { Multicenter } \\
\text { observational } \\
\text { retrospective }\end{array}$ & 2001-2006 & 16065 & 3.1 & 1.59 & - \\
\hline Hamaya [14] & $\begin{array}{l}\text { CBA/RFCA } \\
\text { of AF }\end{array}$ & $\begin{array}{l}\text { Single center } \\
\text { prospective } \\
\text { cohort }\end{array}$ & 2002-2016 & $5222 / 3483$ & 0.98 & 1.96 & $86.3 / 3.9$ \\
\hline Michowitz [15] & $\begin{array}{l}\text { Catheter abla- } \\
\text { tion of } \mathrm{AF}\end{array}$ & $\begin{array}{l}\text { Multicenter } \\
\text { prospective } \\
\text { cohort }\end{array}$ & 2000-2012 & $34942 /$ & 0.84 & 1 & $99 / 16$ \\
\hline $\begin{array}{l}\text { Voskoboinik } \\
{[16]}\end{array}$ & RFCA of AF & $\begin{array}{l}\text { Single center } \\
\text { prospective } \\
\text { observational }\end{array}$ & 2004-2017 & $2750 /$ & 0.18 & 0 & - \\
\hline Hoyt [17] & $\begin{array}{l}\text { Catheter abla- } \\
\text { tion of AF }\end{array}$ & $\begin{array}{l}\text { Single center } \\
\text { prospective }\end{array}$ & 2001-2010 & $/ 1190$ & 1.1 & 0 & $100 / 0$ \\
\hline Dagres [18] & RFCA of AF & $\begin{array}{l}\text { Single center } \\
\text { prospective }\end{array}$ & 2005-2008 & $1000 /$ & 1.3 & 0 & $85 / 15$ \\
\hline Mujović [11] & RFCA & $\begin{array}{l}\text { Single center } \\
\text { prospective }\end{array}$ & 2011-2016 & $1500 / 1352$ & 0.8 & 0 & $100 / 17$ \\
\hline Aldhoon [19] & RFCA of AF & $\begin{array}{l}\text { Single center, } \\
\text { prospective }\end{array}$ & 2006-2010 & $1192 / 959$ & 0.16 & 0 & $100 / 0$ \\
\hline Baman [20] & RFCA of AF & $\begin{array}{l}\text { Single center, } \\
\text { prospective }\end{array}$ & $2007-2010$ & $/ 1295$ & 1.2 & 0 & $100 / 0$ \\
\hline Mugnai [21] & $\begin{array}{l}\text { CBA/RFCA } \\
\text { of AF }\end{array}$ & $\begin{array}{l}\text { Single center } \\
\text { retrospective } \\
\text { cohort }\end{array}$ & 2008-2014 & 13521 & 1.0 & 0 & $92 / 8$ \\
\hline
\end{tabular}

AF - atrial fibrillation, CBA - cryoballoon catheter ablation, PT - pericardial tamponade, PCC - pericardiocentesis, RFCA - radiofrequency catheter ablation. ST - surgical treatment.

Table II. Meta-analyses comparing efficacy and safety of RFCA vs. CBA of AF

\begin{tabular}{lcccc}
$\begin{array}{l}\text { Author(s) } \\
\text { [ref.] }\end{array}$ & $\begin{array}{c}\text { Year of } \\
\text { publication }\end{array}$ & Study range & $\begin{array}{c}\text { Group of } \\
\text { patients }\end{array}$ & $\begin{array}{c}\text { Percentage of pericardial tamponade as procedure complication/ } \\
\text { conclusion }\end{array}$ \\
\hline Jiang [27] & 2017 & $1998-2016$ & 2336 & $\begin{array}{c}\text { CBA 0.4\% vs. RFCA 1.5\% }(\mathrm{OR}=0.32,95 \% \text { Cl: 0.13-0.78, } p=0.01), \\
\text { with no significant heterogeneity }\left(P^{2}=0 \%, p=0.98\right)\end{array}$ \\
\hline Ma [28] & 2017 & $\begin{array}{c}\text { Up to Dec } \\
2016\end{array}$ & 9141 & CBA 1.05\% vs. RFCA 1.86\% $(p=0.02)$ \\
\hline Cardoso [29] & 2016 & $\begin{array}{c}\text { Up to April } \\
2016\end{array}$ & 8668 & CBA 0.3 RFCA 1.4 (OR $=0.31 ; 95 \%$ Cl: 0.15-0.64; $p<0.01)$
\end{tabular}

RFCA - radiofrequency catheter ablation, CBA - cryoballoon catheter ablation, AF-atrial fibrillation.

cardial tamponade between CBA and RFCA. Meanwhile the recent dedicated meta-analyses have shown higher or considerably higher risk of PT in an RF catheter ablation group (Table II) [27-29].

\section{Pericardial tamponade as a result of percutaneous coronary intervention}

Pericardial tamponade is a rare complication of percutaneous coronary intervention (PCI). It is mostly caused by coronary artery perforation (CP) that may occur as the consequence of guide wire advancement, balloon infla- tion or rupture, and utilization of atherectomy devices [30, 31]. It usually occurs after grade III CP as defined by the Ellis criteria [32]. However, RV perforation due to temporary pacing wires was also found to be an important cause of PT $[33,34]$.

Pericardial tamponade following a CP is frequently associated with poor outcomes and may increase the risk of death by more than 3 fold $(\mathrm{OR}=3.3 ; 95 \% \mathrm{Cl}$ : $1.01-10.65 ; p=0.047$ ) compared with patients who sustained CP without PT [35]. The incidence and predictors of CP have been studied in several large PCl series [30, 
31, 36-43]. Generally summarizing, the reported risk factors for perforation include elderly patients, female gender, previous coronary artery bypass grafting, and use of rotational and laser atherectomy. Also $\mathrm{PCl}$ of chronic total occlusion (CTO) may be associated with higher risk for procedural complications, including coronary perforation. In the summary analysis from 65 studies by Patel et al., 419 perforations of 18061 patients undergoing CTO PCI were reported. In this series, the reported rate of CP was $2.9 \%$ with a tamponade frequency of $0.2 \%$ [44].

Most $\mathrm{PCl}$ studies are focused on coronary artery perforation as the major complication, mentioning and calculating PT within this group. In a meta-analysis by Shimony et al. [45] involving 197061 PCls, the pooled incidence of CP was $0.43 \%$. The overall percentage of PT after CP was 19.3 (11.9-28.9). In our review CP leads to PT in 11.5-35\% (Table III).

The large, multicenter, prospectively collected and retrospectively analyzed study from the British Cardiovascular Intervention Society Database counting 527121 cases revealed 470 (0.89\%) patients having PT as a complication after $\mathrm{PCl}, 222$ patients in the group with CP $(14.18 \%)$ and 248 in the group without CP (0.05\%) [36]. In the previous studies the percentage of PT was higher, $0.12 \%$ and $1.21 \%[33,42]$.

In most PCl studies, PT was diagnosed in the cardiac catheterization laboratory by echocardiography or by fluoroscopy that revealed immobile heart borders or the extravasation of the blood from CP. However, late presentation (up to $24 \mathrm{~h}$; mean time 2-4) has tended to occur. In the study by Fejka et al. [42] 14 of 31 PT had late appearance of PT (mean time: $4.4 \mathrm{~h}$ ) and the most frequent mode of presentation was progressive hypotension culminating in 5 patients in cardiac arrest. In their study PT was associated with very high overall mortality (42\%), while $64 \%$ of patients presenting PT required intra-aortic balloon pump, ventilatory support and blood transfusion, $61 \%$ cardiopulmonary resuscitation and 35\% transvenous pacemaker implantation.

The treatment of CP depends on the perforated structure. With coronary perforations, a variety of approaches are possible by prolonged balloon inflation in addition to reversing anticoagulation, covered stents if the artery is large enough to accommodate these devices, or embolization for small vessels [4].

\section{Pericardial tamponade as a result of permanent heart rhythm device implantation}

The use of implantation of permanent heart rhythm devices (PHRD), which include permanent pacemakers (PPM) and implantable cardioverter defibrillators (ICD), is increasing due to the expansion of indications and aging

Table III. Studies concerning information about rate of coronary perforation and pericardial tamponade as a complication of percutaneous coronary intervention, PT-related mortality, management and outcomes, up to December 2018

\begin{tabular}{|c|c|c|c|c|c|c|c|}
\hline Author(s) [ref.] & $\begin{array}{l}\text { Type of } \\
\text { procedure }\end{array}$ & Type of study & Time interval & $\begin{array}{l}\text { No. of } \\
\text { procedures/ } \\
\text { patients }\end{array}$ & $\begin{array}{c}N(\%) \\
\text { PT per all } \\
\text { procedures } \\
\text { No. of CP/PT }\end{array}$ & $\begin{array}{c}\text { PT-related } \\
\text { mortality (\%) }\end{array}$ & $\begin{array}{c}N(\%) \\
\text { PCC/ST }\end{array}$ \\
\hline Kinnaird [36] & $\mathrm{PCl}$ & $\begin{array}{c}\text { Multicenter } \\
\text { prospectively } \\
\text { collected } \\
\text { database }\end{array}$ & 2006-2013 & $527121 /$ & $\begin{array}{c}0.089 \% \\
1762 \text { CP (from } \\
\text { which } 14 \% \text { PT) }\end{array}$ & - & $97 / 3$ \\
\hline Von Sohsten [33] & $\mathrm{PCl}$ & $\begin{array}{l}\text { Single center } \\
\text { prospective }\end{array}$ & 1994-1996 & 6999/ & $0.21 \%$ & 0 & $73 / 60$ \\
\hline Fejka [42] & $\mathrm{PCl}$ & $\begin{array}{l}\text { Single center } \\
\text { prospective }\end{array}$ & 1993-2000 & $25697 /$ & $0.12 \%$ & 42 & $61 / 39$ \\
\hline Stathopoulos [35] & $\mathrm{PCl}$ & $\begin{array}{l}\text { Single center } \\
\text { prospective }\end{array}$ & 1999-2006 & 23 399/ & $\begin{array}{c}0.11 \% \\
73 \text { CP (from } \\
\text { which } 35 \% \text { PT) }\end{array}$ & 7.7 & $100 / 11.5$ \\
\hline Shimony [40] & $\mathrm{PCl}$ & $\begin{array}{l}\text { Single center } \\
\text { prospective }\end{array}$ & 2001-2008 & 19568 & $\begin{array}{c}57 \text { CP (from } \\
\text { which 16\% PT) }\end{array}$ & - & - \\
\hline Kiernan [38] & $\mathrm{PCl}$ & $\begin{array}{l}\text { Single center } \\
\text { retrospective }\end{array}$ & 2000-2008 & 14 281/ & $\begin{array}{c}68 \text { CP (from } \\
\text { which 17\% PT) }\end{array}$ & - & - \\
\hline Fasseas [41] & $\mathrm{PCl}$ & $\begin{array}{l}\text { Single center } \\
\text { retrospective }\end{array}$ & 1990-2001 & /16 298 & $\begin{array}{c}95 \text { CP (from } \\
\text { which } 11.5 \% \\
\text { PT) }\end{array}$ & - & - \\
\hline Danek [43] & CTO PCl & $\begin{array}{l}\text { Multicenter } \\
\text { prospective }\end{array}$ & 2012-2017 & 2097/2049 & $\begin{array}{c}85 \text { CP (from } \\
\text { which 14\% PT) }\end{array}$ & - & - \\
\hline
\end{tabular}


of the population. Despite the fact that post-implantation pericardial effusion can be a sign of lead perforation (LP), there are other mechanisms leading to pericardial effusion, such as traumatic inflammation of the myocardium and pericardium from the lead screw, or irritation of the visceral pericardium via immune mediated mechanisms [46].

Lead perforation is a rare complication after PHRD implantation and may involve large veins, atrial or ventricular walls or coronary sinus. LP develops most often acutely (i.e., less than $24 \mathrm{~h}$ after the procedure), which may potentially result in PT or death. Also it can occur $24 \mathrm{~h}$ after the device implantation in a subacute or chronic fashion. Another classification distinguishes between early (symptoms occur up to 1 month after implantation) and delayed perforations [47].

The clinical presentation of LP may be different in the late form, with most patients presenting pacemaker malfunction, stabbing chest pain and shortness of breath. A distinguishing feature of delayed in opposition to acute LP is the decrease or absence of PT or death [48]. Published event rates for LP range from $0.1 \%$ to $0.8 \%$ for PPM and $0.14-5.2 \%$ for ICD leads; in those publications perforations occurred mostly within 1 month after implantation [48-50] (Table IV).

Factors that are thought to contribute to acute LP are similar to those in late LP: patient characteristics, concomitant therapies such as steroids or anticoagulants, implant techniques and the design characteristics of the lead [49]. Patient-related factors in PPM implantations include old age, female sex, low body mass index and for ICD implantations it is additionally worsened heart failure class, left bundle branch block and non-single-chamber ICD implant [50]. Thin heart muscle itself, such as in a patient with myotonic muscular dystrophy and dilated cardiomyopathy, may favor perforation [51]. The use of atrial leads, helical screw ventricular leads, active fixation and temporary stimulation was reported to increase the incidence of perforation [47, 52]. The risk factors concerning defibrillator leads are as follows: double spirals, number of shocks delivered, excessive length or small diameter of the lead, high resistance (small tip surface) and apical position $[47,53]$.

Ohlow et al. [46] prospectively observed 968 consecutive patients undergoing PHRD implantations who had undergone echocardiographic evaluation before and $24 \mathrm{~h}$ after the operation. Fourteen of them (1.44\%) had had PT requiring pericardiocentesis $(n=12 ; 86 \%)$ or surgical treatment $(n=2,14 \%)$. In 10 of those patients a hemorrhagic effusion suggested cardiac perforation of an implanted lead; acute pericarditis was observed in the remaining four patients.

In the latest study Moazzami et al. [54] reported their findings after analyzing the United States National Inpatient Sample (USNIS) database from 922549 patients implanted with PPM. PT occurred in 2695 (0.28\%) patients. The authors found that female sex, implantation of dual-chamber pacemakers, and chronic liver disease predicted greater odds of PT, whereas hypertension and atrial fibrillation were associated with lower odds of tamponade. The association of chronic liver disease with PT may be related to the potential for bleeding due to coagulopathy, systemic tissue characteristics from liver disease, or anatomic consideration from hepatomegaly. The protective association of atrial fibrillation may be related to implantation of fewer atrial leads, enlarged LA or atrial fibrosis, whereas hypertension may be related to hypertrophy of the cardiac chambers [55].

Temporary transvenous pacing (TTP) with electrodes guided to the RV is burdened with the risk of PT as well.

Table IV. Studies concerning information about rate of pericardial tamponade as a complication of selected electrophysiology procedures, PT-related mortality, management and outcomes, up to December 2018

\begin{tabular}{|c|c|c|c|c|c|c|c|}
\hline Author(s) [ref.] & $\begin{array}{l}\text { Type of } \\
\text { procedure }\end{array}$ & Type of study & Time interval & $\begin{array}{l}\text { No. of } \\
\text { procedures/ } \\
\text { patients }\end{array}$ & $\begin{array}{c}N(\%) \\
\text { PT or LP } \\
\text { per all } \\
\text { procedures }\end{array}$ & $\begin{array}{c}\text { PT-related } \\
\text { mortality (\%) }\end{array}$ & $\begin{array}{l}N(\%) \\
\text { PCC/ST }\end{array}$ \\
\hline Moazzami [54] & PPM & $\begin{array}{l}\text { Multicenter } \\
\text { retrospective }\end{array}$ & 2008-2012 & 1922549 & $0.28 \mathrm{PT}$ & 6.7 & - \\
\hline Ohlow [46] & $\begin{array}{c}\text { PHRD } \\
\text { PPM } \\
\text { ICD }\end{array}$ & $\begin{array}{l}\text { Single center } \\
\text { observational }\end{array}$ & 2007-2010 & 1968 & $\begin{array}{l}\text { All 1.44 PT } \\
\text { PPM 2.6 PT } \\
\text { ICD 0.7 PT }\end{array}$ & $\begin{array}{c}14 \\
\text { PPM } 0 \\
\text { ICD } 14 \\
\end{array}$ & $86 / 14$ \\
\hline Hsu [50] & ICD & $\begin{array}{l}\text { Multicenter } \\
\text { retrospective }\end{array}$ & 2006-2011 & $/ 440251$ & $0.14 \mathrm{LP}$ & 5.6 & - \\
\hline Carlson [49] & $\begin{array}{c}\text { PHRD } \\
\text { PPM } \\
\text { ICD }\end{array}$ & $\begin{array}{l}\text { Multicenter } \\
\text { prospective } \\
\text { (incidence in } \\
\text { OPTIMUM and } \\
\text { ACS registry) }\end{array}$ & 2006-2007 & /5928 & $\begin{array}{l}\text { PPM: } 0.5 \text { LP } \\
\text { ICD: } 0.33 \text { LP }\end{array}$ & - & - \\
\hline Metkus [56] & TTP & $\begin{array}{l}\text { Multicenter } \\
\text { retrospective }\end{array}$ & 2004-2014 & 1360223 & 0.6 PT & 5 & - \\
\hline
\end{tabular}

$C P$ - cardiac perforation, ICD - implantable cardioverter defibrillator, $L P$ - lead perforation, $P T$ - pericardial tamponade, PCC - pericardiocentesis, PPM-permanent pacemaker, PHRD - permanent heart rhythm devices, ST - surgical treatment, TLP - transvenous lead extraction, TTP - temporary transvenous pacing. 
Performing analysis about complications and outcomes of over 360000 TTPs using the USNIS database, Metkus et al. defined the rate of PT as $0.6 \%$ [56].

A review of studies concerning the rate of PT and LP after PHRD implantation, management and PT-related death is presented in Table IV.

With the growing number of PHRD implantations in recent years, in parallel, a rise in lead malfunction and recalls has resulted in increased transvenous lead extractions (TLE) [57]. In 2016 the biggest multicentre prospective overview of TLE safety and efficacy conducted by the EHRA, entitled The European Lead Extraction ConTRolled Registry (ELECTRa), was published [57]. The primary endpoint was TLE safety defined by in-hospital procedure-related major complications including death. In 3510 patients 6493 leads including 4917 (75.7\%) pacing and 1576 (24.3\%) ICD leads were targeted for extraction. The mean dwell time of extracted leads was $6.4 \pm 5.4$ years (median: 5 years, IQR: $2-9$ ). Indications for TLE were infective in $52.8 \%$. Among 58 deaths, 17 were procedure-related. The most common procedure-related complications were cardiovascular complications requiring pericardiocentesis or surgical repair occurring in $49(1.4 \%)$ patients. Apart from thoracic and peripheral vascular lesions, 28 patients had cardiac avulsion and 2 cardiac avulsion with thoracic vascular tears. The clinical manifestations of these complications were PT, haemothorax and hemorrhagic shock. The authors did not report the exact number of PTs, but we may assume that this number may correspond to the number of cases concerning cardiac avulsion [30]. However, the authors provided accurate information about 17 causes of procedure-related deaths. According to their results, PT led to death in 6 cases, undergoing surgical treatment in all of them. This emphasizes what a hazardous complication pericardial tamponade is. Moreover, procedure-related major complications and death were more common in female patients ( $\mathrm{OR}=2.11,95 \% \mathrm{Cl}: 1.23-3.62, p=0.0067)$, leads with a dwell time $>10$ years $(\mathrm{OR}=3.54$, RR: $1.6-$ 7.83, $p=0.0018)$, with the use of powered sheaths $(\mathrm{OR}=2.4,95 \% \mathrm{Cl}: 1.41-4.09, p=0.0013)$ and a femoral approach $(\mathrm{OR}=3.60,95 \% \mathrm{Cl}: 1.64-7.87)$.

\section{Pericardial tamponade as a result of left atrium appendage occlusion}

Occluding the left atrial appendage (LAA) is an alternative treatment for stroke prevention in high-risk patients with contraindications to oral anticoagulants. The risk of causing PT is due to the fact that the LA appendage itself can be extremely thin-walled.

In addition to surgical technique, percutaneous methods of LAA closure were developed. For clinical use both Watchman and the Amplatzer Cardiac Plug (ACP) devices have been approved. Moreover, in 2013 a second generation of the ACP, the Amplatzer Amulet left atrial appendage occluder, was released [58]. The Watchman device is basically a plug that should be precisely implanted to avoid both its protrusion into the LA as well as the creation of a cul-de-sac where thrombus may form. The ACP consists of two parts joined by a central pin. Being short, the ACP can be implanted in a shallow position in the LAA, as only the proximal $2 \mathrm{~cm}$ are needed for its occlusion. The occlusive disc permits the complete closure of the LAA orifice [59]. In a prospective randomized controlled trial by Holmes et al. [60], with the intervention group consisting of 463 LAAC implantations, the most frequent primary safety event was severe pericardial effusion (defined as the need for percutaneous or surgical drainage). It occurred in 22 (4.8\%) patients; 15 of them were treated with pericardiocentesis and 7 underwent surgical intervention. None of those patients died, although length of hospital stay in these patients was longer than in the control group (244 patients) without severe pericardial effusion (median 4 days longer). Effusion rates declined with investigator experience. In a meta-analysis by Wei et al. [61] assessing the efficacy and safety of transcatheter LAA closure in patients with nonvalvular AF, the incidence of pericardial effusion/tamponade was estimated as 0.02 (95\% Cl: 0.02-0.03). The studies assessing the rate of PT, its management and PT-related mortality after LAA closure are summarized in Table V.

\section{Pericardial tamponade as a result of transcatheter aortic valve implantation (TAVI)}

The European Society of Cardiology guidelines advocate the use of TAVI in patients with severe aortic stenosis and high risk for SAVR (surgical aortic valve replacement), favoring TAVI mostly in older patients [62]. In a retrospective cohort study evaluating 16755 patients diagnosed with AS in the Japanese healthcare setting, in-hospital outcomes between TAVI and SAVR were evaluated. The incidence of pericardial tamponade was significantly higher in the SAVR patients $(1.5 \%$ in SAVR vs. $0.5 \%$ in TAVI; $p=$ 0.03 [ [63]. There are three major pathophysiological situations that may lead to PT during TAVI: first, annular or aortic root rupture during balloon valvuloplasty and valve implantation with subsequent arterial bleeding into the pericardium; second, perforation of the right RV caused by the temporary pacing lead; and third, perforation of the LV by an extra-stiff guidewire during its placement or at later stages of the procedure $[64,65]$. In existing literature, PT has been described as occurring in $0.2-4.3 \%$ of cases, with a higher probability in retrograde trans-vascular techniques than with trans-apical access $[66,67]$ (Table V).

\section{Pericardial tamponade as a result of percutaneous mitral valve repair with the Mitra-Clip system}

Percutaneous edge-to-edge mitral valve repair using the Mitra-Clip device represents a less invasive 
Table V. PT-related mortality, management and outcomes in selected cardiac procedures, up to December 2018

\begin{tabular}{|c|c|c|c|c|c|c|c|}
\hline Author(s) [ref.] & $\begin{array}{l}\text { Type of } \\
\text { procedure }\end{array}$ & Type of study & Time interval & $\begin{array}{c}\text { No. of } \\
\text { procedures/ } \\
\text { patients }\end{array}$ & $\begin{array}{c}N(\%) \\
\text { PT per all } \\
\text { procedures }\end{array}$ & $\begin{array}{c}\text { PT-related } \\
\text { mortality (\%) }\end{array}$ & $\begin{array}{l}N(\%) \\
\text { PCC/ST }\end{array}$ \\
\hline Guerios [59] & LAAC & $\begin{array}{l}\text { Single center } \\
\text { prospective }\end{array}$ & 2009-2011 & 196 & 1.1 & - & - \\
\hline Matsuo [71] & LAAC & $\begin{array}{l}\text { Single center } \\
\text { prospective }\end{array}$ & 2009-2012 & $/ 179$ & 1.1 & 0 & $100 / 0$ \\
\hline Berti [72] & LAAC & $\begin{array}{l}\text { Single center } \\
\text { prospective }\end{array}$ & $2009-2014$ & $/ 110$ & 2.7 & 0 & - \\
\hline Kim [73] & LAAC & $\begin{array}{l}\text { Single center } \\
\text { prospective }\end{array}$ & 2010-2015 & 196 & 2 & 50 & - \\
\hline Holmes [60] & LAAC & $\begin{array}{l}\text { Multicenter } \\
\text { randomized }\end{array}$ & $2005-2008$ & $463 /$ & 4.8 & 0 & $68 / 32$ \\
\hline Hamm [66] & $\begin{array}{l}\text { TV AVI } \\
\text { TA AVI }\end{array}$ & $\begin{array}{l}\text { Multicenter } \\
\text { prospective }\end{array}$ & 2011 & $\begin{array}{l}12695 \\
/ 1181 \\
\end{array}$ & $\begin{array}{l}1.4 \\
0.2 \\
\end{array}$ & - & - \\
\hline Rezq [67] & TAVI & $\begin{array}{l}\text { Single center } \\
\text { retrospective }\end{array}$ & 2007-2012 & 1389 & 4.3 & 23.5 & $100 / 29$ \\
\hline Eggebrecht [69] & Mitra-Clip & $\begin{array}{l}\text { Multicenter } \\
\text { prospective }\end{array}$ & 2010-2013 & 1828 & 1.9 & - & $100 / 0$ \\
\hline Maisano [70] & Mitra-Clip & $\begin{array}{l}\text { Multicenter } \\
\text { prospective }\end{array}$ & 2011-2012 & 1567 & 1.1 & - & - \\
\hline
\end{tabular}

LAAC - left atrial appendage closure, Mitra-Clip - percutaneous mitral valve repair with the Mitra-Clip system, PT-pericardial tamponade, PCC - pericardiocentesis, ST - surgical treatment, TAVI - transcatheter aortic valve implantation, transvascular (TV) or transapical (TA) aortic valve implantation (AVI).

treatment option for patients with symptomatic severe mitral regurgitation [68]. With the need for cardiologic techniques such as trans-septal puncture as well as navigation of catheter devices within the LA and LV, the risk of tamponade may grow. There are two large prospective multicenter studies that have analyzed the risk and outcomes of complications during and after Mitra-Clip based on the German Transcatheter Mitral Valve Interventions register [69] and the European ACCESS-EU registry [70] (Table $\mathrm{V}[60,66,67,69-73])$. The risk of PT was $1.9 \%$ and $1.1 \%$ respectively, suggesting that transseptal puncture followed by advancement of the $24 \mathrm{Fr}$ guiding sheath is safe [69].

\section{Discussion}

Pericardial tamponade is a rare complication of invasive cardiac procedures, mostly associated with poor outcomes. It generally develops acutely, but late forms with atypical presentation may occur. The incidence depends on patients' comorbidities, concomitant pharmacotherapy, sex, age, operators' skills, the size of the device responsible for the perforation, the structure of the heart that is perforated, the hemodynamic state during perforation and mechanical properties of the pericardium itself. Some procedures, especially those requiring transseptal puncture or perioperative anticoagulation, favor CT.

Summarizing our review, the overall rate of iatrogenic PT varies among published studies from 0.089 to $4.8 \%$, with the highest rate after left atrial appendage closure, transcatheter aortic valve implantation, and atrial fibril- lation ablation. Concerning electrophysiological procedures, the rate of PT was quite divergent between multicenter and single center studies (Tables I, IV). Generally, the PT-related post-procedural mortality ranged from $0 \%$ to $50 \%$ (medium $7.3 \%$ ) and was highest in LAAC and TAVI groups, then $\mathrm{PCl}, \mathrm{PHRD}$ and the $\mathrm{AF}$ ablation procedures respectively. The need for surgical treatment after iatrogenic PT ranged from $0 \%$ to $60 \%$ (medium 15\%). The most frequent group of PTs requiring surgical treatment was the PCl group, the second group consisted of LAAC and TAVI procedures and the last group consisted of AF ablation and PHRD procedures. These conclusions may not be precise. Many of the mentioned studies only determine predictors of iatrogenic PT or the endpoint of those studies was only the rate of PT, and a follow-up was not performed.

Additionally, we have observed that older age and female sex were common risk factors predisposing to PT. Some techniques as well as echocardiographic or fluoroscopic guidance during such procedures may decrease the overall complication rate.

\section{Conclusions}

Pericardial tamponade is a rare complication of invasive cardiac procedures with the overall rate of iatrogenic PT varying among published studies from $0.089 \%$ to $4.8 \%$, with the highest rate after left atrial appendage closure, transcatheter aortic valve implantation, and atrial fibrillation ablation. latrogenic CT was associated with poor outcomes as high incidence of in-hospital death and need for surgical intervention. 


\section{Conflict of interest}

The authors declare no conflict of interest.

\section{References}

1. Spodick DH. Acute cardiac tamponade. N Engl J Med 2003; 349: 684-90.

2. Reddy PS, Curtiss El, O’Toole JD, et al. Cardiac tamponade: hemodynamic observations in man. Circulation 1978; 58: 265-72.

3. Bunch T, Asirvatham S, Friedman P, et al. Outcomes after cardiac perforation during radiofrequency ablation of the atrium. J Cardiovasc Electrophysiol 2005; 16: 1172-9.

4. Holmes DR, Nishimura R, Fountain R, et al. latrogenic pericardial effusion and tamponade in the percutaneous intracardiac intervention era. JACC Cardiovasc Interv 2009; 2: 705-17.

5. De Ponti R, Cappato R, Curnis A, et al. Trans-septal catheterization in the electrophysiology laboratory: data from a multicenter survey spanning 12 years. J Am Coll Cardiol 2006; 47: 1037-42.

6. Ross J. Transseptal left heart catheterization a 50-year odyssey. J Am Coll Cardiol 2008; 51: 2107-15.

7. Calkins H, Kuck KH, Cappato R, et al. 2012 HRS/EHRA/ECAS expert consensus statement on catheter and surgical ablation of atrial fibrillation: recommendations for patient selection, procedural techniques, patient management and follow-up, definitions, endpoints, and research trial design. J Interv Card Electrophysiol 2012; 33: 171-257.

8. Calkins H, Hindricks G, Cappato R, et al. 2017 HRS/EHRA/ECAS/ APHRS/SOLAECE expert consensus statement on catheter and surgical ablation of atrial fibrillation: Executive summary. Heart Rhythm 2017; 14: e445-94.

9. Cappato R, Calkins H, Chen SA, et al. Prevalence and causes of fatal outcome in catheter ablation of atrial fibrillation. J Am Coll Cardiol 2009; 53: 1798-803.

10. Ellis ER, Culler SD, Simon AW, et al. Trends in utilization and complications of catheter ablation for atrial fibrillation in Medicare beneficiaries. Heart Rhythm 2009; 6: 1267-73.

11. Mujović N, Marinković M, Marković N, et al. Management and outcome of periprocedural cardiac perforation and tamponade with radiofrequency catheter ablation of cardiac arrhythmias: a single medium-volume center experience. Adv Ther 2016; 33: 1782-96.

12. O'Neill MD, Jaïs P, Derval N, et al. Two techniques to avoid surgery for cardiac tamponade occurring during catheter ablation of atrial fibrillation. J Cardiovasc Electrophysiol 2008; 19: 323-5.

13. Venkatachalam KL, Fanning LJ, Willis EA, et al. Use of an autologous blood recovery system during emergency pericardiocentesis in the electrophysiology laboratory. J Cardiovasc Electrophysiol 2009; 20: 280-3.

14. Hamaya R, Miyazaki S, Taniguchi $\mathrm{H}$, et al. Management of cardiac tamponade in catheter ablation of atrial fibrillation: single-centre 15 year experience on 5222 procedures. Europace 2018; 20: 1776-82.

15. Michowitz Y, Rahkovich M, Oral H, et al. Effects of sex on the incidence of cardiac tamponade after catheter ablation of atrial fibrillation: results from a worldwide survey in 34943 atrial fibrillation ablation procedures. Circ Arrhythm Electrophysiol 2014; 7: 274-80

16. Voskoboinik A, Sparks PB, Morton JB, et al. Low rates of major complications for radiofrequency ablation of atrial fibrillation maintained over 14 years: a single centre experience of 2750 consecutive cases. Heart Lung Circ 2018; 72: 976-83.

17. Hoyt H, Bhonsale A, Chilukuri K, et al. Complications arising from catheter ablation of atrial fibrillation: temporal trends and predictors. Heart Rhythm 2011; 8: 1869-74.

18. Dagres N, Hindricks G, Kottkamp H, et al. Complications of atrial fibrillation ablation in a high-volume center in 1,000 procedures: still cause for concern? J Cardiovasc Electrophysiol 2009; 20: 1014-9.

19. Aldhoon B, Wichterle D, Peichl P, et al. Complications of catheter ablation for atrial fibrillation in a high-volume centre with the use of intracardiac echocardiography. Europace 2013; 15: 24-32.

20. Baman TS, Jongnarangsin K, Chugh A, et al. Prevalence and predictors of complications of radiofrequency catheter ablation for atrial fibrillation. J Cardiovasc Electrophysiol 2011; 22: 626-31.

21. Mugnai G, Irfan G, de Asmundis C, et al. Complications in the setting of percutaneous atrial fibrillation ablation using radiofrequency and cryoballoon techniques: a single-center study in a large cohort of patients. Int J Cardiol 2015; 196: 42-9.

22. Deshmukh A, Patel NJ, Pant S, et al. In-hospital complications associated with catheter ablation of atrial fibrillation in the United States between 2000 and 2010: analysis of 93801 procedures. Circulation 2013; 128: 2104-12.

23. Elayi CS, Darrat Y, Suffredini JM, et al. Sex differences in complications of catheter ablation for atrial fibrillation: results on 85,977 patients. J Interv Card Electrophysiol 2018; 53: 333-9.

24. Luik A, Radzewitz A, Kieser M, et al. Cryoballoon versus open irrigated radiofrequency ablation in patients with paroxysmal atrial fibrillation: the prospective, randomized, controlled, noninferiority FreezeAF Study. Circulation 2015; 132: 1311-9.

25. Aryana A, Singh SM, Kowalski M, et al. Acute and long-term outcomes of catheter ablation of atrial fibrillation using the second-generation cryoballoon versus open-irrigated radiofrequency: a multicenter experience. J Cardiovasc Electrophysiol 2015; 26: 832-9.

26. Kuck KH, Brugada J, Fürnkranz A, et al. Cryoballoon or radiofrequency ablation for paroxysmal atrial fibrillation. $N$ Engl J Med 2016; 374: 2235-45.

27. Jiang J, Li J, Zhong G, et al. Efficacy and safety of the second-generation cryoballoons versus radiofrequency ablation for the treatment of paroxysmal atrial fibrillation: a systematic review and meta-analysis. J Interv Card Electrophysiol 2017; 48: 69-79.

28. Ma H, Sun D, Luan $H$, et al. Efficacy and safety of cryoballoon ablation versus radiofrequency catheter ablation in atrial fibrillation: an updated meta-analysis. Adv Interv Cardiol 2017; 13: 240-9.

29. Cardoso R, Mendirichaga R, Fernandes G, et al. Cryoballoon versus radiofrequency catheter ablation in atrial fibrillation: a meta-analysis. J Cardiovasc Electrophysiol 2016; 27: 1151-9.

30. Dippel EJ, Kereiakes DJ, Tramuta DA, et al. Coronary perforation during percutaneous coronary intervention in the era of abciximab platelet glycoprotein IIb/IIla blockade: an algorithm for percutaneous management. Catheter Cardiovasc Interv 2001; 52: 279-86.

31. Gruberg L, Pinnow E, Flood R, et al. Incidence, management, and outcome of coronary artery perforation during percutaneous coronary intervention. Am J Cardiol 2000; 86: 680-2.

32. Ellis SG, Ajluni S, Arnold AZ, et al. Increased coronary perforation in the new device era. Incidence, classification, management, and outcome. Circulation 1994; 90: 2725-30. 
33. von Sohsten R, Kopistansky C, Cohen M, et al. Cardiac tamponade in the "new device" era: evaluation of 6999 consecutive percutaneous coronary interventions. Am Heart J 2000; 140: 279-83.

34. Nashed G, French B, Gallagher D, et al. Right ventricular perforation with cardiac tamponade associated with use of a temporary pacing wire and abciximab during complex coronary angioplasty. Catheter Cardiovasc Interv 1999; 48: 388-9.

35. Stathopoulos I, Kossidas K, Panagopoulos G, et al. Cardiac tamponade complicating coronary perforation during angioplasty: short-term outcomes and long-term survival. J Invasive Cardiol 2013; 25: 486-91.

36. Kinnaird T, Kwok CS, Kontopantelis E, et al. Incidence, determinants, and outcomes of coronary perforation during percutaneous coronary intervention in the united kingdom between 2006 and 2013: an analysis of 527121 cases from the British Cardiovascular Intervention Society Database. Circ Cardiovasc Interv 2016; 9: e003449.

37. Parsh J, Seth M, Green J, et al. Coronary artery perforations after contemporary percutaneous coronary interventions: evaluation of incidence, risk factors, outcomes, and predictors of mortality. Catheter Cardiovasc Interv 2017; 89: 966-73.

38. Kiernan T, Yan Bp, Ruggiero N, et al. Coronary artery perforations in the contemporary interventional era. J Interv Cardiol 2009; 22: 350-3.

39. Hendry C, Fraser D, Eichhofer J, et al. Coronary perforation in the drug-eluting stent era: incidence, risk factors, management and outcome: the UK experience. Eurointervention 2012; 8: 79-86.

40. Shimony A, Zahger D, Van Straten $M$, et al. Incidence, risk factors, management and outcomes of coronary artery perforation during percutaneous coronary intervention. Am J Cardiol 2009; 104: 1674-7.

41. Fasseas P, Orford JL, Panetta CJ, et al. Incidence, correlates, management, and clinical outcome of coronary perforation: analysis of 16,298 procedures. Am Heart J 2004; 147: 140-5.

42. Fejka M, Dixon SR, Safian RD, et al. Diagnosis, management, and clinical outcome of cardiac tamponade complicating percutaneous coronary intervention. Am J Cardiol 2002; 90: 1183-6.

43. Danek BA, Karatasakis A, Tajti P, et al. Incidence, treatment, and outcomes of coronary perforation during chronic total occlusion percutaneous coronary intervention. Am J Cardiol 2017; 120 : 1285-92.

44. Patel Y, Depta TJ, DeMartini TJ. Complications of chronic total occlusion percutaneous coronary intervention. Interv Cardiol 2013; 5: 567-75.

45. Shimony A, Joseph L, Mottillo S, et al. Coronary artery perforation during percutaneous coronary intervention: a systematic review and meta-analysis. Can J Cardiol 2011; 27: 843-50.

46. Ohlow MA, Lauer B, Brunelli $M$, et al. Incidence and predictors of pericardial effusion after permanent heart rhythm device implantation. Circ J 2013; 77: 975-81.

47. Piekarz J, Lelakowski J, Rydlewska A, et al. Heart perforation in patients with permanent cardiac pacing - pilot personal observations. Arch Med Sci 2012; 8: 70-4.

48. Khan MN, Joseph G, Khaykin Y, et al. Delayed lead perforation: a disturbing trend. Pacing Clin Electrophysiol 2005; 28: 251-3.

49. Carlson M, Freedman R, Levine P. Lead perforation: incidence in registries. Pacing Clin Electrophysiol 2007; 31: 13-5.

50. Hsu JC, Varosy PD, Bao H, et al. Cardiac perforation from implantable cardioverter-defibrillator lead placement: insights from the National Cardiovascular Data Registry. Circ Cardiovasc Qual Outcomes 2013; 6: 582-90.

51. Sterlinski M, Przybylski A, Maciag A, et al. Subacute cardiac perforations associated with active fixation leads. Europace 2008; 11: 206-12.

52. Mahapatra S, Bybee KA, Bunch TJ, et al. Incidence and predictors of cardiac perforation after permanent pacemaker placement. Heart Rhythm 2005; 2: 907-11.

53. Akbarzadeh MA, Mollazadeh R, Sefidbakht S, et al. Identification and management of right ventricular perforation using pacemaker and cardioverter-defibrillator leads: a case series and mini review. J Arrhythmia 2017; 33: 1-5.

54. Moazzami K, Dolmatova E, Kothari N, et al. Trends in cardiac tamponade among recipients of permanent pacemakers in the United States: from 2008 to 2012. JACC Clin Electrophysiol 2017; 3: 41-6.

55. Hsu JC. Cardiac tamponade from permanent pacemaker implantation: is the pressure building? JACC Clin Electrophysiol 2017; 3: 47-9.

56. Metkus TS, Schulman SP, Marine JE, et al. Complications and outcomes of temporary transvenous pacing. Chest 2019; 155: 749-57.

57. Bongiorni MG, Kennergren C, Butter C, et al. The European Lead Extraction ConTRolled (ELECTRa) study: a European Heart Rhythm Association (EHRA) Registry of transvenous lead extraction outcomes. Eur Heart J 2017; 38: 2995-3005.

58. Gloekler S, Shakir S, Doblies J, et al. Early results of first versus second generation Amplatzer occluders for left atrial appendage closure in patients with atrial fibrillation. Clin Res Cardiol 2015; 104: 656-65.

59. Guérios ÊE, Schmid M, Gloekler S, et al. Oclusão do apêndice atrial esquerdo com o Amplatzer Cardiac Plug em pacientes com fibrilação atrial. Arq Bras Cardiol 2012; 98: 528-36.

60. Holmes DR, Reddy VY, Turi ZG, et al. Percutaneous closure of the left atrial appendage versus warfarin therapy for prevention of stroke in patients with atrial fibrillation: a randomised non-inferiority trial. Lancet 2009; 374: 534-42.

61. Wei Z, Zhang X, Wu H, et al. A meta-analysis for efficacy and safety evaluation of transcatheter left atrial appendage occlusion in patients with nonvalvular atrial fibrillation. Medicine 2016; 95: e4382.

62. Baumgartner H, Falk V, Bax J, et al. 2017 ESC/EACTS Guidelines for the management of valvular heart disease. Eur Heart J 2017; 38: 2739-91.

63. Umegaki T, Kunisawa S, Nakajima Y, et al. Comparison of in-hospital outcomes between transcatheter and surgical aortic valve replacement in patients with aortic valve stenosis: a retrospective cohort study using administrative data. J Cardiothorac Vasc Anesth 2018; 32: 1281-8.

64. Möllmann H, Kim WK, Kempfert J, et al. Complications of transcatheter aortic valve implantation (TAVI): how to avoid and treat them. Heart 2015; 101: 900-8.

65. Ali N, Patel PA, Lindsay SJ. Recent developments and controversies in transcatheter aortic valve implantation. Eur J Heart Fail 2018; 20: 642-50.

66. Hamm CW, Mollmann H, Holzhey D, et al. The German Aortic Valve Registry (GARY): in-hospital outcome. Eur Heart J 2014; 35: 1588-98.

67. Rezq A, Basavarajaiah S, Latib A, et al. Incidence, management, and outcomes of cardiac tamponade during transcatheter aortic valve implantation. JACC Cardiovasc Interv 2012; 5: 1264-72. 
68. Feldman T, Wasserman HS, Herrmann HC, et al. Percutaneous mitral valve repair using the edge-to-edge technique. J Am Coll Cardiol 2005; 46: 2134-40.

69. Eggebrecht H, Schelle S, Puls M, et al. Risk and outcomes of complications during and after MitraClip implantation: experience in 828 patients from the German TRAnscatheter Mitral valve Interventions (TRAMI) registry. Catheter Cardiovasc Interv 2015; 86: 728-35.

70. Maisano F, Franzen O, Baldus S, et al. Percutaneous Mitral Valve Interventions in the Real World. J Am Coll Cardiol 2013; 62: 1052-61.

71. Matsuo Y, Sandri M, Mangner N, et al. Interventional closure of the left atrial appendage for stroke prevention. Circ J 2014; 78 : 619-24.

72. Berti S, Pastormerlo LE, Rezzaghi M, et al. Left atrial appendage occlusion in high-risk patients with non-valvular atrial fibrillation. Heart 2016; 102: 1969-73.

73. Kim JS, Lee H, Suh Y, et al. Left atrial appendage occlusion in non-valvular atrial fibrillation in a Korean Multi-Center Registry. Circ J 2016; 80: 1123-30. 